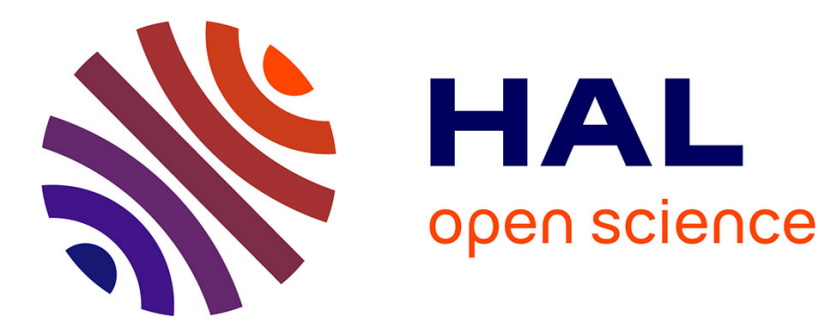

\title{
Design Principles for High Frequency Power Transformer Materials
}

M. Bogs, W. Holubarsch

\section{To cite this version:}

M. Bogs, W. Holubarsch. Design Principles for High Frequency Power Transformer Materials. Journal de Physique IV Proceedings, 1997, 07 (C1), pp.C1-117-C1-118. 10.1051/jp4:1997136 . jpa-00255083

\section{HAL Id: jpa-00255083 https://hal.science/jpa-00255083}

Submitted on 1 Jan 1997

HAL is a multi-disciplinary open access archive for the deposit and dissemination of scientific research documents, whether they are published or not. The documents may come from teaching and research institutions in France or abroad, or from public or private research centers.
L'archive ouverte pluridisciplinaire HAL, est destinée au dépôt et à la diffusion de documents scientifiques de niveau recherche, publiés ou non, émanant des établissements d'enseignement et de recherche français ou étrangers, des laboratoires publics ou privés. 


\title{
Design Principles for High Frequency Power Transformer Materials
}

\author{
M. Bogs and W. Holubarsch \\ Siemens Matsushita Components GmbH \& Co KG, S+M FER M ME, P.O. Box 801709, 81617 Munich, \\ Germany
}

\begin{abstract}
To meet the size and weight requirements of modern switching power supplies new ferrite materials with low losses in a $100 \mathrm{kHz}-1 \mathrm{MHz}$ frequency range are ueeded. Examplary the development of an improved version of the well known material N49 [1] designated as N49i is discussed. The development of this new material results substantially in the reduction of the core losses (by about 20\%) compared with the conventional one within the frequency range around $500 \mathrm{kHz}$ at operating temperature area around $80^{\circ} \mathrm{C}$. In connection with $\mathrm{N} 49$ considerations important design principles in high performance power ferrites are discussed generally. This is concerned with a detailed lineup of suitable materials for the frequency range from $100 \mathrm{kHz}$ up to $1 \mathrm{MHz}$. The perfornance of power ferrites $\mathrm{N} 87, \mathrm{~N} 49$ and $\mathrm{N} 59$ is judged by its maximum fxB-product for a given dissipation level, a good measure for the attainable throughput power for a design. It is shown that the improved N49 version leads to an optimized gradation between the materials N87, N49 and N59. Futhermore the correlations between frequency dependent maximum of perfonmance factor, grain size and $\mathrm{AC}$-resistance behaviour are analysed.
\end{abstract}

\section{INTRODUCTION}

The usual way to reduce the size of switching powver supplies is to increase the switching frequency because the throughput power $P_{t h}$ of a ferrite transformer is directly proportional to the operating frequency $f$, the maximum allowed magnetic flux density $B_{\max }$ and the magnetic cross section $A$ according to $P_{t h} \sim A f B_{\max }$. It is easily to be seen, that higher value of the $\left(\mathrm{fB}_{\max }\right)$ product would allow smaller core volumes to transform the same amount of power as a larger core would be able at lower $\left(\mathrm{fB}_{\mathrm{max}}\right)$ product. Because this product named "Performance Factor" is material-dependent, a good high frequency ferrite exhibit a high $\left(\mathrm{fB}_{\max }\right)$ value [2]. However, at high frequencies and at high induction levels the magnetic loss that accompanies the magnetization process is an important phenomenon which limits the throughput power.

\section{POWER LOSSES}

Total core losses $P_{L}$ in ferrites split up into eddy current losses $P_{e}$, residual losses $P_{T}$ and hysteresis losses $P_{b}$. While hysteresis and eddy current losses are predominant up to frequencies of $500 \mathrm{kHz}$ behind this also residual losses, which are a combination of relaxation and resonant losses caused by the delay in magnetization equilibrium, must be taken into account. The sum of essential eddy current losses $P_{e}$ and residual losses $P_{r}$ denoted often only as eddy current losses $P_{e}^{\prime}=\left(P_{L}-P_{h}\right)$. The different loss parts can be expressed by:

$$
P_{e}^{\prime}=c f^{x} B^{y} d^{2} / \rho \text { and } P_{h}=f \int H d B,
$$

where $f$ is the frequency, $B$ is the flux density. $H$ is the magnetic field strength, $d$ is the average grain diameter, $\rho$ is the bulk resistivity and $\mathbf{c}$ is the proportional constant $[3,4]$. With respect to this relations a minimization of eddy current losses necessary especially for frequencies above $500 \mathrm{kHz}$ is probable by reduction of $d$ and increase of $\rho$. This includes the need to produce an uniform and fine microstructure with high-resistance boundaries and grains. Beside eddy current losses also hysteresis losses $P_{h}$ must be controlled every tine. The $B / H$ curve is a closed curve and its area is a measure for the amount of hysteresis losses. It is also known that at high induction levels domain wall displacements occur and hindrances in the grains to these domain wall movements may give rise to high hysteresis loss. To lower hysteresis losses, the magnetocrystalline anisotropy constant $k_{1}$, the magnetostriction constant $\lambda$. the internal or external stress $\sigma$ and the volume fraction of inclusions $v$ should be low. Whereas $k_{1}$ and $\lambda$ are mainly controlled by the chemical composition, $\sigma$ and $v$ are dependent on impurity level in the grains and at the boundary [3]. Additionally grain sizes should not be excessively low.

In respect to different loss mechanisms discussed above must be accepted a few contradictionary requirements for low loss power ferrites: A small grain size which increase resistivity by maximizing the grain boundary surface and additives such as $\mathrm{Ca}-\mathrm{SiO}_{2}$ which increase the grain boundery resistivity increase the hysteresis loss but decrease the eddy current loss. This corresponds with a decrease of the permeability and an increase of the relaxation frequency and the coercive force $[5,6]$. 


\section{DEVELOPMENT OF NEW POWER LOSS MATERIAL "N49I"}

An improved version of power ferrite $\mathrm{N49}$ (designated as N49i) with the same initial permeability $\left(\mu_{\mathrm{i}}\right)$ and reduced in losses $\left(\mathrm{P}_{\mathrm{L}}\right)$ by about $20 \%$ for frequencies around $500 \mathrm{kHz}$ was developed by realizing an optimized balance between hysteresis losses and eddy current losses (Tab. 1). Furthermore the magnetic flux density $\left(B_{m}\right)$ was improved essentially by increasing the sintering density. These improvements were achieved by applying similar design principles as for the the recently developed power ferrite $\mathrm{N} 59$, designed for $\mathrm{MHz}$ range [1]. In detail these are the use of high purity raw materials, similar composition and additives, adapted powder reactivity and firing conditions. All these measures result in an uniform microstructure with thin and high resistance grain boundaries as well as in a high density fired body with an average grain size, which is about twice as much that of N59. Finally such a microstructure leads to an optimized relationship between AC-resistivity $(\rho)$ and average grain size (d), necessary for the desired loss reduction.

\begin{tabular}{|c|c|c|c|c|c|c|}
\hline Property & Unit & \multicolumn{2}{|c|}{ Condition } & N59 & N49i & $\mathrm{N} 49$ \\
\hline$\mu_{i}$ & - & \multicolumn{2}{|c|}{$10 \mathrm{kHz} 0,25 \mathrm{mTT}$} & 850 & 1300 & 1300 \\
\hline density & $\mathrm{g} / \mathrm{cm}^{3}$ & \multicolumn{2}{|c|}{-} & 4,75 & 4,75 & 4,55 \\
\hline $\bar{d}$ & $\mu \mathrm{m}$ & & 5 & 10 & 12 \\
\hline$\rho_{A C}$ & $\overrightarrow{\Omega m}$ & \multicolumn{2}{|c|}{$500 \mathrm{kHz}$} & 5,0 & $\overline{5,5}$ & 3,5 \\
\hline$T_{c}$ & ${ }^{\circ} \mathrm{C}$ & \multicolumn{2}{|c|}{-} & $>240$ & $>240$ & $>220$ \\
\hline \multirow[t]{2}{*}{$\overline{\mathrm{B}_{\mathrm{m}}}$} & $\mathrm{mI}$ & $10 \mathrm{kHz}$ & $25^{\circ} \mathrm{C}$ & 460 & 460 & 410 \\
\hline & & $1200 \mathrm{~A} / \mathrm{m}$ & $100^{\circ} \mathrm{C}$ & 370 & 370 & 300 \\
\hline $\mathrm{H}_{\mathrm{c}}$ & $\mathrm{A} / \mathrm{m}$ & & $\begin{array}{r}25^{\circ} \mathrm{C} \\
100^{\circ} \mathrm{C}\end{array}$ & $\begin{array}{l}60 \\
50\end{array}$ & $\begin{array}{l}50 \\
45\end{array}$ & $\begin{array}{l}35 \\
25\end{array}$ \\
\hline$\overline{P_{L}}$ & $\mathrm{~kW} / \mathrm{m}^{3}$ & $\begin{array}{c}500 \mathrm{kHz} \\
50 \mathrm{mT}\end{array}$ & $\begin{array}{r}25^{\circ} \mathrm{C} \\
50^{\circ} \mathrm{C} \mathrm{C} \\
80^{\circ} \mathrm{C} \\
100^{\circ} \mathrm{C}\end{array}$ & $\begin{array}{l}272 \\
208 \\
175 \\
174\end{array}$ & $\begin{array}{l}146 \\
107 \\
100 \\
120\end{array}$ & $\begin{array}{l}145 \\
127 \\
131 \\
156\end{array}$ \\
\hline
\end{tabular}

Table 1: Representative standard material characteristics of material N49i in comparison to materials N59 and N49 (measured on ring cores R29)

\section{PERFORMANCE FACTOR}

Due to different core loss optimizations three different power materials can be considered in the frequency range from $100 \mathrm{kHz}$ to $1.5 \mathrm{MHz}$. In Fig. 1 the Performance Factor (PF) versus frequency of the materials N87, N49/N49i and N59 is plotted for a dissipation level of $300 \mathrm{~mW} / \mathrm{cm}^{3}$ at $100^{\circ} \mathrm{C}$, a good measure for the attainable throughput power for a design. It is shown that $\mathrm{N} 49 \mathrm{i}$ material was tuned to an maximum ( $\mathrm{fB}_{\text {max. }}$ ) product of $37.000 \mathrm{HzT}$ at $900 \mathrm{kHz}$, a essentially higher value as realized with $\mathrm{N} 49$, which leads to an optimized gradation between the materials N87, N49 and N59.

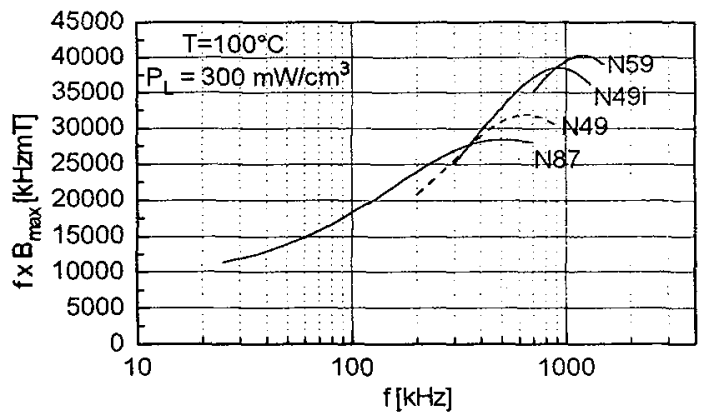

Figure 1: Performance Factor versus frequency at $100^{\circ} \mathrm{C}$ tor a dissipation level of $300 \mathrm{~mW} / \mathrm{cm}^{3}$

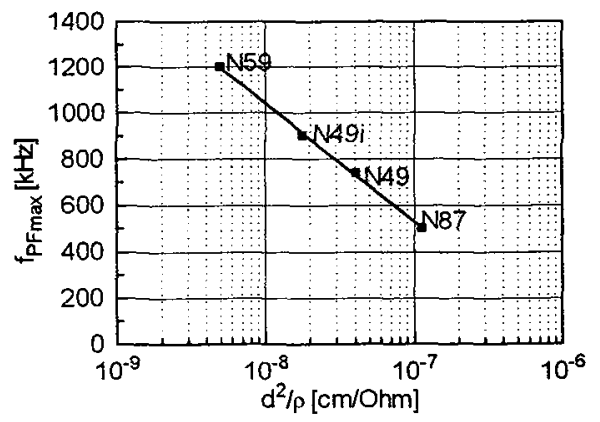

Figure 2: Relationship between $\left(d^{2} / \rho\right)$ and frequency of maximum of Performance Factor.

Fig. 2 illustrates the correlation between frequency of Performance Factor maximum, grain size d and AC-resistivity $\rho$. This behaviour correlates well with former findings in respect to the relation between eddy current loss and $\mathrm{d}^{2} / \rho[3,4]$. Based on frequency dependence of $\rho$ it can be asssumed that at lower frequency the insulating grain boundary layer dominates in the total electrical behaviour whereas in the higher frequency range the grain boundaries are almost short circuited by their capacitance and the resulting resistivity, allowing eddy currents. decreases slowly to the level of the resistivity of the crystallites.

\section{References}

[1] Bogs M., Esguerra M., Holubarsch W., "New Ferrite Material for High Frequency Power Transformers", Proc. 26th Power Conversion Conference, Nuernberg 1991, pp. 361-370.

[2] Visser E. G., Shilman A., PCIM Europe (January/February 1992) 24-26.

[3] Sano T., Morita A., Matsukawa A., "A New Ferrite for High Frequency Power Ferrites", Proc. 3rd Ann. High Frequency

Power Conversion Conference, San Diego 1988. pp. 85-99.

[4] Otsuki E., Yamada S., Ceramics Transactions 47 (1995) 147-154.

[5] Nomura T., Ochiai T., Ceramics Transactions 47 (1995) 211-226.

[6] Lebourgeois R., Deljurie C.. Ganne J.P., Perriat P., Lloret B., Rolland J.L., "New MnZn Low-Loss Power Ferrite for Frequencies up to IMHz: Influence of Grain Size and Oxidization Rate on Elektromagnetic Properties, Proc. ICF6, Tokyo and Kyoto 1992, pp. 1169-1172. 